\title{
Brassinosteroid accelerates the growth of Psidium hybrid during acclimatization of seedlings obtained from minicuttings ${ }^{1}$
}

\author{
Mariana Barreto de Souza Arantes², Claudia Sales Marinho², Mara de Menezes de Assis Gomes ${ }^{3}$, \\ Raudielle Ferreira dos Santos², Sydney Pereira Galvão², Giuliana Pulitini Vaz ${ }^{2}$
}

\section{ABSTRACT}

Guava rootstocks can be multiplied by minicuttings in environment with a high relative humidity, being necessary an acclimatization period. Certain growth regulators favor the acclimatization, with brassinosteroids being successfully used in other fruit plants. This study aimed to shorten the multiplication time of the BRS Guaraça hybrid by applying Biobras-16 (BB-16) during the acclimatization of seedlings obtained from minicuttings. The treatments consisted of five BB-16 concentrations $\left(0,0.1,0.3,0.5\right.$ and $\left.1.0 \mathrm{mg} \mathrm{L}^{-1}\right)$, applied in a randomized block design, in a split-plot arrangement, with four replications and five seedlings per plot, repeated at two seasons: winter and spring/summer. After 60 days of acclimatization, shoot and root growth indicators increased as a function of the BB-16 application, particularly at concentrations between 0.3 and $0.6 \mathrm{mg} \mathrm{L}^{-1}$. The brassinosteroid can be used to stimulate the growth of BRS Guaraçá seedlings obtained from minicuttings, shortening its production time and improving its seedling quality.

KEYWORDS: Plant growth regulator, guava rootstock, BRS Guaraçá.

\section{INTRODUCTION}

Brazil is the world's fourth largest guava producer, after India, China and Pakistan (Altendorf 2018), with an annual production of 578,000 metric tons in 2018, concentrated primarily in the states of Pernambuco and São Paulo, and predominantly aimed at the domestic market (IBGE 2020).

Guava seedlings are generally produced by vegetative propagation, using herbaceous cuttings of commercial varieties (Yamamoto et al. 2010).

\section{RESUMO}

Brassinosteroide acelera o crescimento de híbrido de Psidium durante aclimatação de mudas obtidas por miniestaquia

Porta-enxertos para goiabeira podem ser multiplicados por miniestaquia em ambiente com alta umidade relativa, sendo necessário um período para aclimatação. Alguns reguladores de crescimento favorecem a aclimatação, sendo os brassinosteroides utilizados com sucesso em outras frutíferas. Objetivou-se reduzir o tempo de multiplicação do híbrido BRS Guaraçá com aplicações de Biobras-16 (BB-16) na fase de aclimatação de mudas obtidas por miniestaquia. Os tratamentos consistiram de cinco concentrações de BB-16 ( $0 ; 0,1 ; 0,3 ; 0,5 ;$ e $\left.1,0 \mathrm{mg} \mathrm{L}^{-1}\right)$, aplicadas em delineamento experimental com blocos casualizados, em esquema de parcelas subdivididas, com quatro repetições e cinco mudas por parcela, repetidos em duas épocas do ano: inverno e primavera/verão. Ao final de sessenta dias de aclimatação, indicadores de crescimento da parte aérea e raízes tiveram incrementos em função da aplicação de BB-16, notadamente nas concentrações entre 0,3 e $0,6 \mathrm{mg} \mathrm{L}^{-1}$. $\mathrm{O}$ brassinosteroide pode ser utilizado para estimular o crescimento de mudas de BRS Guaraçá oriundas de miniestaquia, reduzindo o seu tempo de produção e incrementando sua qualidade.

PALAVRAS-CHAVE: Regulador de crescimento vegetal, portaenxertos para goiabeira, BRS Guaraçá.

The minicutting technique may also be used, since no differences have been found between minicuttings and herbaceous cuttings, in terms of survival and rooting (Altoé \& Marinho 2012). However, this form of propagation makes crops vulnerable to the nematode Meloidogne enterolobii, which, in sinergy with the fungal pathogen Fusarium sp., causes the plant death (Gomes et al. 2010). Crops infested with $M$. enterolobii sustain high economic losses (Pereira et al. 2009). An alternative for cultivation in contaminated areas is the use of hybrid rootstocks

\footnotetext{
${ }^{1}$ Received: July 30, 2020. Accepted: Oct. 27, 2020. Published: Nov. 25, 2020. DOI: 10.1590/1983-40632020v5064743.

${ }^{2}$ Universidade Estadual do Norte Fluminense, Laboratório de Fitotecnia, Campos dos Goytacazes, RJ, Brasil. E-mail/ORCID: mariana.arant@yahoo.com.br/0000-0001-9755-0671, claudia.marinho@uenf.br/0000-0001-6636-6468, raudielle@outlook.com/ 0000-0003-0801-7491, sydneygalvaoagro@gmail.com/0000-0002-7540-1859,giuliana_vaz@hotmail.com/0000-0002-4849-7285.

${ }^{3}$ Universidade Estadual do Norte Fluminense, Laboratório de Melhoramento Genético Vegetal, Campos dos Goytacazes, RJ, Brasil.E-mail/ORCID: mara.assis.gomes@gmail.com/0000-0002-9204-1883.
} 
developed by cross resistant and compatible genotypes, such as $P$. guajava $(\mathrm{L}) \times$.$P . guineense$ (Sw.) (Costa et al. 2012), P. cattleianum $\mathrm{x}$ P. guinense and $P$. guajava $\mathrm{x} P$. cattleianum (Gomes et al. 2017).

In this respect, the production of grafted guava seedlings should become a new reality in commercial nurseries, with rootstock production as the first step to be optimized. Minicuttings show a great potential for guava farming, since they shorten the production time and provide propagative material under conditions that allow a better disease control (Marinho et al. 2009, Altoé \& Marinho 2012, Altoé et al. 2013). However, the technique is incipient in commercial propagation and can be optimized, for example, by applying growth regulators at specific stages of the production process, including the rootstock production. When obtained in high relative humidity environments, rootstocks require a period of acclimatization and growth to reach the optimal stage for grafting.

Certain plant growth regulators favor acclimatization, and brassinosteroids have shown to be efficient for this purpose in several fruit trees (Catunda et al. 2008, Freitas et al. 2012, Zheng et al. 2017, Gomes et al. 2018). Brassinosteroids are a class of plant steroid hormones that act in cell elongation, allowing plant growth (Baghel et al. 2019). However, their effect is dependent on the plant growth stage (Freitas et al. 2015), applied concentration (Freitas et al. 2014, Wei \& Li 2016) and presence or absence of environmental stress (Tanveer et al. 2019).

This study aimed to shorten the production time of BRS Guaraçá seedlings for use as guava rootstock. To that end, brassinosteroid applications were evaluated during the acclimatization of seedlings produced by rooting minicuttings.

\section{MATERIAL AND METHODS}

The study was conducted at the Universidade Estadual do Norte Fluminense, in Campos dos Goytacazes, Rio de Janeiro state, Brazil, from June to August 2018, representing the first experimental period (winter), and November to December 2018, as the second period (between spring and summer). A randomized block design was used, with split-plots and four replications (five plants per plot), repeated at two times of the year (experimental periods).

It was carried out in a greenhouse and the minicuttings were rooted in an intermittent mist chamber, where the average maximum and minimum temperatures were $26.7^{\circ} \mathrm{C}$ and $19.7^{\circ} \mathrm{C}$ in the winter and $27.4^{\circ} \mathrm{C}$ and $21.9^{\circ} \mathrm{C}$ in the spring/summer, with respective maximum and minimum relative humidity of $89.6 \%$ and $55.0 \%$ and $87.0 \%$ and $61.7 \%$, in these same periods.

The maximum and minimum temperature and relative humidity were also measured in the greenhouse during both experimental periods, with respective values of $26.6^{\circ} \mathrm{C}$ and $20.2^{\circ} \mathrm{C}$ and $87.6 \%$ and $53.7 \%$ in the spring/summer, and $31.3{ }^{\circ} \mathrm{C}$ and $24.4{ }^{\circ} \mathrm{C}$ and $86.6 \%$ and $59.1 \%$ in the winter. The measurements were obtained using a digital caliper.

The treatments consisted of five concentrations $\left(0,0.1,0.3,0.5\right.$ and $\left.1.0 \mathrm{mg} \mathrm{L}^{-1}\right)$ of a brassinosteroid analogue (polyhydroxylated spirostane), under the commercial name Biobras-16 (BB-16), sprayed onto the rootstock seedlings during acclimatization.

The plantlets used in the experiments were produced by vegetative propagation of BRS Guaraçá, a hybrid of Psidium guajava (L.) and Psidium guineense (Sw.), obtained from the Empresa Brasileira de Pesquisa Agropecuária (Embrapa Semiárido). The material was maintained in a greenhouse, under a clonal mini-garden system. The protocol followed to produce seedlings from minicuttings was described by Altoé \& Marinho (2012). The seedlings were pruned to stimulate new sprouts and produce minicuttings.

The minicuttings were prepared from an herbaceous branch, which was segmented to produce another cutting containing two pairs of leaves. The basal leaves were removed and the apical leaves cut in half. Next, the minicuttings were placed in $280 \mathrm{~cm}^{3}$ tubes containing Basaplant ${ }^{\mathrm{TM}}$ commercial substrate for vegetables and transferred to a mist chamber for 60 days. The moisture content in the mist chamber was maintained above $70 \%$, using a mister (Fogger ${ }^{\mathrm{TM}}$ ) that sprayed for 15 seconds every 10 minutes (flow rate and pressure of $7 \mathrm{~L} \mathrm{~h}^{-1}$ and $4.0 \mathrm{kgf} \mathrm{cm}^{-2}$, respectively). After 60 days, the minicuttings were moved to a greenhouse covered with $70 \%$ shade cloth to acclimatize for 60 days. On the first day of acclimatization, the seedlings were sprayed with $5 \mathrm{~mL}$ of BB-16 per plot, at the different concentrations used in the experiment, and every six days thereafter until day thirty, after which the sprout length continued to be assessed over the final 30 days of acclimatization.

The used brassinosteroid analogue was Biobras-16 (BB-16, polyhydroxylated spirostane), 
provided by the Instituto Agronômico de Campinas (IAC), but synthesized by the National Institute of Agricultural Sciences in San José de Las Lajas, Havana, Cuba.

Throughout the experiment, the plants in all treatments were submitted to foliar fertilization with $0.1 \%$ of urea applied every two weeks, as well as a nutrient solution containing $\mathrm{NaH}_{2} \mathrm{PO}_{4}(1 \mathrm{M})$; $\mathrm{Ca}\left(\mathrm{NO}_{3}\right)_{2} \cdot 4 \mathrm{H}_{2} \mathrm{O}(2 \mathrm{M}) ; \mathrm{KNO}_{3}(1 \mathrm{M}) ; \mathrm{K}_{2} \mathrm{SO}_{4}(2 \mathrm{M})$; $\mathrm{MgSO}_{4}(2.5 \mathrm{M})$; and $\left(\mathrm{NH}_{4}\right)_{2} \mathrm{SO}_{4}(1.5 \mathrm{M})$, and a solution "a" containing $\mathrm{H}_{3} \mathrm{BO}_{3}\left(0.4122 \mathrm{~g} \mathrm{~L}^{-1}\right) ; \mathrm{MnCl}_{2} \cdot 4 \mathrm{H}_{2} \mathrm{O}$ (1.98 $\left.\mathrm{g} \mathrm{L}^{-1}\right) ; \mathrm{CuSO}_{4} .5 \mathrm{HO}\left(0.24968 \mathrm{~g} \mathrm{~L}^{-1}\right) ; \mathrm{MoO}_{3}$ $\left(0.0431 \mathrm{~g} \mathrm{~L}^{-1}\right)$; and $\mathrm{ZnSO}_{4} .7 \mathrm{H}_{2} \mathrm{O}\left(0.28755 \mathrm{~g} \mathrm{~L}^{-1}\right)$, corrected to $\mathrm{pH} 5.5$ and applied weekly using a pipette, at a volume of $20 \mathrm{~mL}$ per tube via the substrate (Bolle-Jones 1954).

The sprout length was measured every six days after emergence, using a digital pachymeter. When two sprouts emerged, only one was measured and the other removed. After 60 days, the sprout diameter (measured in the middle of the sprout), internode length and number of leaves were also assessed. The leaf area was determined using a LICOR ${ }^{\mathrm{TM}}$ LI-3100 area meter. The roots were processed for scanning using the WinRhizo ${ }^{\text {TM }}$ software, and their diameter, volume, length and area calculated. The leaf, stem and root dry weight were determined using an analytical scale, after the material was dried in a forced air oven at $70^{\circ} \mathrm{C}$, for three days.

The data were submitted to analysis of variance and, when significant at $5 \%$ according to the F-test, the means of the BB-16 concentrations underwent a regression analysis.

\section{RESULTS AND DISCUSSION}

The seedlings treated with BB-16 showed a significant increase $(\mathrm{p}<0.05)$ in sprout length, particularly at a concentration of $0.3 \mathrm{mg} \mathrm{L}^{-1}$, exhibiting sprouts 3 (Figure 1a) to 3.7 times longer (Figure 1b) in the winter and spring/summer, respectively, than the control, after 54 days of acclimatization.

In Tabebuia alba seedlings, the foliar application of a brassinosteroid and gibberellin increased the stem and petiole growth rates, related to a greater xyloglucan endotransglucosylase activity, with the brassinosteroid also raising the number of epidermal and mesophyll cells (Ono et al. 2000).

Papaya seedlings height increased when the plant canopy was treated with BB-16 over three

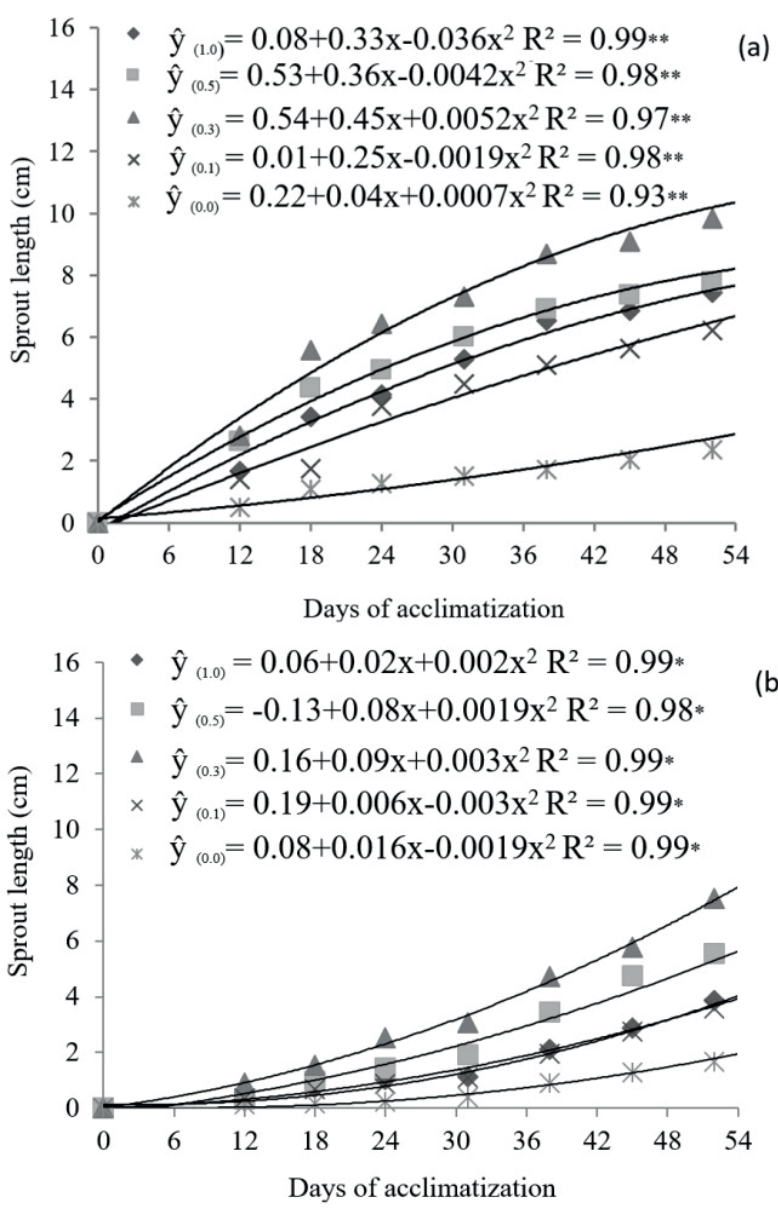

Figure 1. Sprout length of BRS Guaraçá seedlings [P. guajava (L.) $\mathrm{x}$ P. guineense (Sw.)] multiplied via minicuttings and treated with increasing concentrations of BB-16 over a 60-day acclimatization period in the winter (a) and spring/summer (b). ** and * significant at 1 and $5 \%$ of probability, respectively.

consecutive days, indicating that the regulator may have stimulated shoot apex cells (Gomes et al. 2018). The growth resulting from the application of a brassinosteroid analogue to plants may be related to its regulation of aquaporin activity in the plasma membrane, since these proteins improve the cell wall flexibility, cell expansion and plant growth (Morillon et al. 2001).

In seedlings treated with BB-16, the increase in the leaf area was 4.8 times greater in the winter (Figure 2a), at an estimated concentration of $0.55 \mathrm{mg} \mathrm{L}^{-1}$, and 4.6 times higher in the spring/ summer, at $0.52 \mathrm{mg} \mathrm{L}^{-1}$ (Figure $2 \mathrm{~b}$ ). The number of leaves increased 2-fold in the winter, at an estimated dose of $0.59 \mathrm{mg} \mathrm{L}^{-1}$ (Figure 2c), and 2.5-fold in the spring/summer, at $0.56 \mathrm{mg} \mathrm{L}^{-1}$ (Figure $2 \mathrm{~d}$ ). 

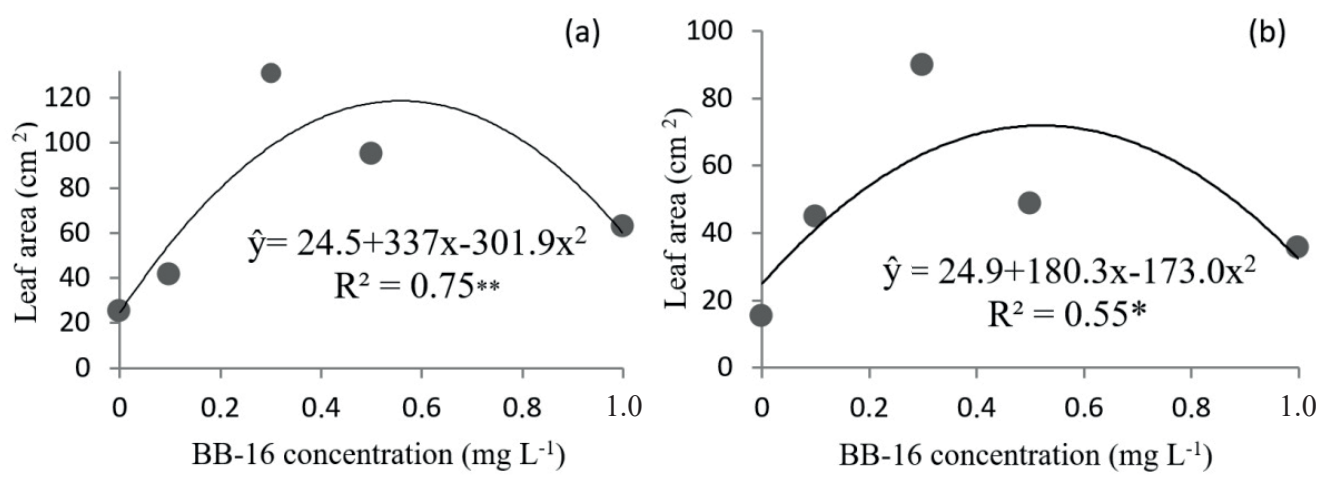

(c)
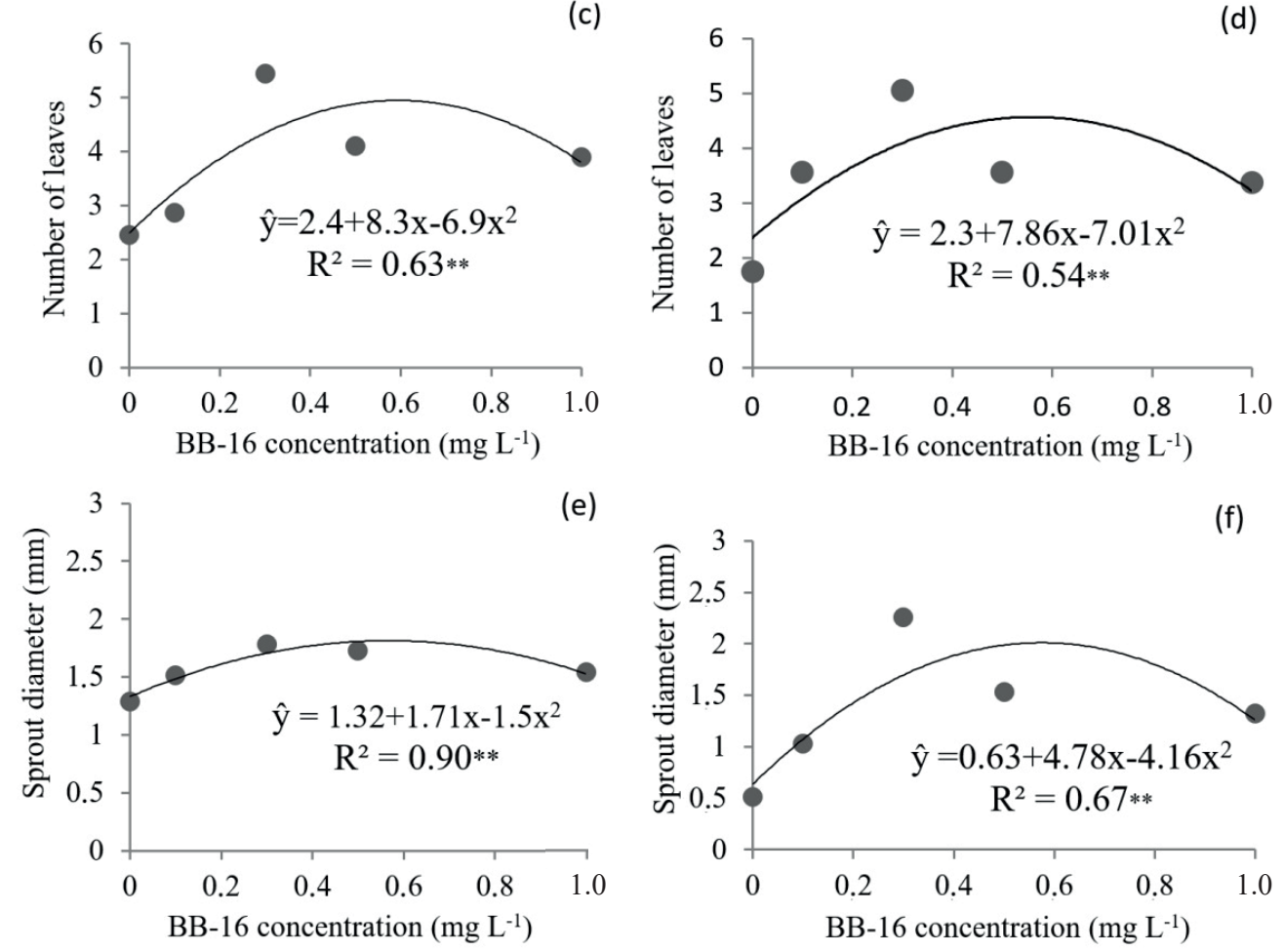

Figure 2. Leaf area in the winter (a) and spring/summer (b), number of leaves in the winter (c) and spring/summer (d), and sprout diameter in the winter (e) and spring/summer (f) of BRS Guaraça seedlings [P. guajava (L.) x P. guineense (Sw.)] multiplied via minicuttings and treated with increasing concentrations of BB-16 over a 60 -day acclimatization period. ** and * significant at 1 and $5 \%$ of probability, respectively.

The maximum sprout diameter was obtained at BB-16 concentrations of $0.56 \mathrm{mg} \mathrm{L}^{-1}$ and $0.57 \mathrm{mg} \mathrm{L}^{-1}$, representing increases 1.3 and 4.0 times greater than the controls for plants treated in the winter (Figure 2e) and spring/summer (Figure 2f), respectively.

The results indicate that the BB-16 application was effective at increasing the leaf area, number of leaves and sprout diameter. Oh et al. (2014) observed cell elongation in Arabidopsis thaliana with natural concentrations of brassinosteroid. This effect was related to shared regulation pathways among the plant hormones auxin, brassinsteroid and gibberellin.
As such, the increase in the characteristics assessed may be related to the interaction among these pathways, intensified by the BB-16 application. The application of brassinosteroid and gibberellin had a positive synergistic effect on the seedlings growth (Ono et al. 2000). In general, gibberellins promote cell elongation, increasing the xyloglucan endotransglucosylase activity and weakening the cell wall. Cellulose microbifibrils are subsequently eradicated and new ones inserted into the cell wall (Taiz \& Zeiger 2009). In this context, the brassinosteroid spraying produced an increase in plant 
mass and size, possibly due to the interaction between the brassinosteroid and gibberellin growth promoters.

Carica papaya L. seedlings sprayed with $1 \mathrm{mg} \mathrm{L}{ }^{-1}$ of BB-16 exhibited different results, in relation to the number of leaves, varying the application mode. The treatment of the whole canopy provided the greatest increase in the number of leaves, with a decline in this variable when only the youngest or oldest leaves were treated. This effect may be related to the fact that the BB-16 application delayed the leaf senescence in the canopy (Gomes et al. 2018). Zheng et al. (2017) observed a greater vegetative growth, indicated by the canopy diameter, branch length and diameter in Moringa oleifera plants treated with 2.4 -epibrassinolide $\left(0.8 \mathrm{mg} \mathrm{plant}^{-1}\right)$ applied directly to the soil.

Freitas et al. (2014) found that the use of BB-16 in pineapple seedlings increased the slip length, leaf area, number of leaves and sprout diameter at estimated doses of $0.79 \mathrm{mg} \mathrm{L}^{-1}, 0.75 \mathrm{mg} \mathrm{L}^{-1}$, $0.64 \mathrm{mg} \mathrm{L}^{-1}, 0.68 \mathrm{mg} \mathrm{L}^{-1}$ and $0.68 \mathrm{mg} \mathrm{L}^{-1}$, respectively. On the other hand, Santos et al. (2014) studied the 'Smooth Cayenne' pineapple cultivar and reported that $0.50,0.75,1.0$ and $1.25 \mathrm{mg} \mathrm{L}^{-1}$ of BB-16, in the presence and absence of humic acid, did not increase the leaf area or diameter, number of leaves, root volume or root and shoot dry weight.

In the present study, BRS Guaraçá seedlings treated with BB-16 exhibited a larger leaf area and sprout diameter and more leaves, especially at concentrations between 0.3 and $0.6 \mathrm{mg} \mathrm{L}^{-1}$ (Figure 2). During the acclimatization of micropropagated 'Imperial' pineapple seedlings, the dry matter accumulation was 2.8 times greater in plants treated with $0.1 \mathrm{mg} \mathrm{L}^{-1}$ of BB-16, when compared to controls grown in commercial substrate. The rosette diameter and leaf width also increased at 0.1 and $0.3 \mathrm{mg} \mathrm{L}^{-1}$, respectively, in seedlings cultivated in commercial substrate (Catunda et al. 2008). Freitas et al. (2012) reported that $0.79 \mathrm{mg} \mathrm{L}^{-1}$ of BB-16 improved the seedling growth and $0.64 \mathrm{mg} \mathrm{L}^{-1}$ increased the number of leaves, while a dose of $0.75 \mathrm{mg} \mathrm{L}^{-1}$ increased the leaf area and sprout diameter, in seedlings removed from the stem of 'Smooth Cayenne' pineapple plants.

In the present study, the seedlings treated with BB-16 exhibited longer roots and a higher root dry weight. At an estimated concentration of $0.55 \mathrm{mg} \mathrm{L}^{-1}$, the plants treated in the winter exhibited 3.0-fold longer roots then the control
(Figure 3a), while the root growth in those treated with $0.51 \mathrm{mg} \mathrm{L}^{-1}$ during the spring/summer was 3.4 times higher (Figure $3 b$ ).

In regard to the root dry weight of BB-16treated seedlings, values were 3 and 4.6 times higher at $0.54 \mathrm{mg} \mathrm{L}^{-1}$ in the winter (Figure 3c) and $0.51 \mathrm{mg} \mathrm{L}^{-1}$ in the spring/summer (Figure 3d), respectively.

Seedlings obtained from cuttings present a growing difficulty during acclimatization, because their poorly functional adventitious roots prevent them from absorbing enough water and nutrients (Hoffmann 2002). In this respect, the use of brassinosteroids during this period is important for improving the root volume and quality.

Brassinosteroids have a positive effect on root growth, promoting cell proliferation. Arabidopsis thaliana mutants with defective brassinosteroid biosynthesis have shorter roots due to their low cell expansion rate (Wei \& Li 2016).

Based on the obtained results, it can be inferred that BB-16 concentrations between $0.3 \mathrm{mg} \mathrm{L}^{-1}$ and $0.6 \mathrm{mg} \mathrm{L}^{-1}$ contributed to the shoot and root growth in BRS Guaraçá seedlings, in both experimental periods (winter and spring/summer).

The brassinosteroid had a significant effect on leaf and stem dry weight, as well as root volume and area $(\mathrm{p}<0.05)$. The leaf and stem dry weight in plants treated in the winter were 5.9 and 2.4 times higher at estimated concentrations of $0.52 \mathrm{mg} \mathrm{L}^{-1}$ and $0.5 \mathrm{mg} \mathrm{L}^{-1}$, respectively. The root area and volume were 2.2 -fold greater at $0.56 \mathrm{mg} \mathrm{L}^{-1}$ and $0.57 \mathrm{mg} \mathrm{L}^{-1}$, respectively. Root diameter was the only characteristic that showed no significant effect (Table 1).

Seedlings treated in the spring/summer showed a 4.5 times greater leaf dry weight and 3 times higher stem dry weight at $0.50 \mathrm{mg} \mathrm{L}^{-1}$ and $0.44 \mathrm{mg} \mathrm{L}^{-1}$, respectively, while the root volume and area were 2.4 times greater than the controls at $0.48 \mathrm{mg} \mathrm{L}^{-1}$ (Table 1).

Catunda et al. (2008) studied the effect of BB-16 concentrations during the acclimatization of micropropagated 'Imperial' pineapple seedlings and found that the dry matter production was 2.8 times higher at doses of $0.1 \mathrm{~g} \mathrm{~L}^{-1}$, with the regulator proving to be more effective in plants grown in substrate with a greater nutrient availability. Freitas et al. (2012) reported that $0.68 \mathrm{mg} \mathrm{L}^{-1}$ of BB-16 increased the dry matter and shoot nitrogen content in seedlings removed from the stem of 'Smooth Cayenne' pineapple plants. 

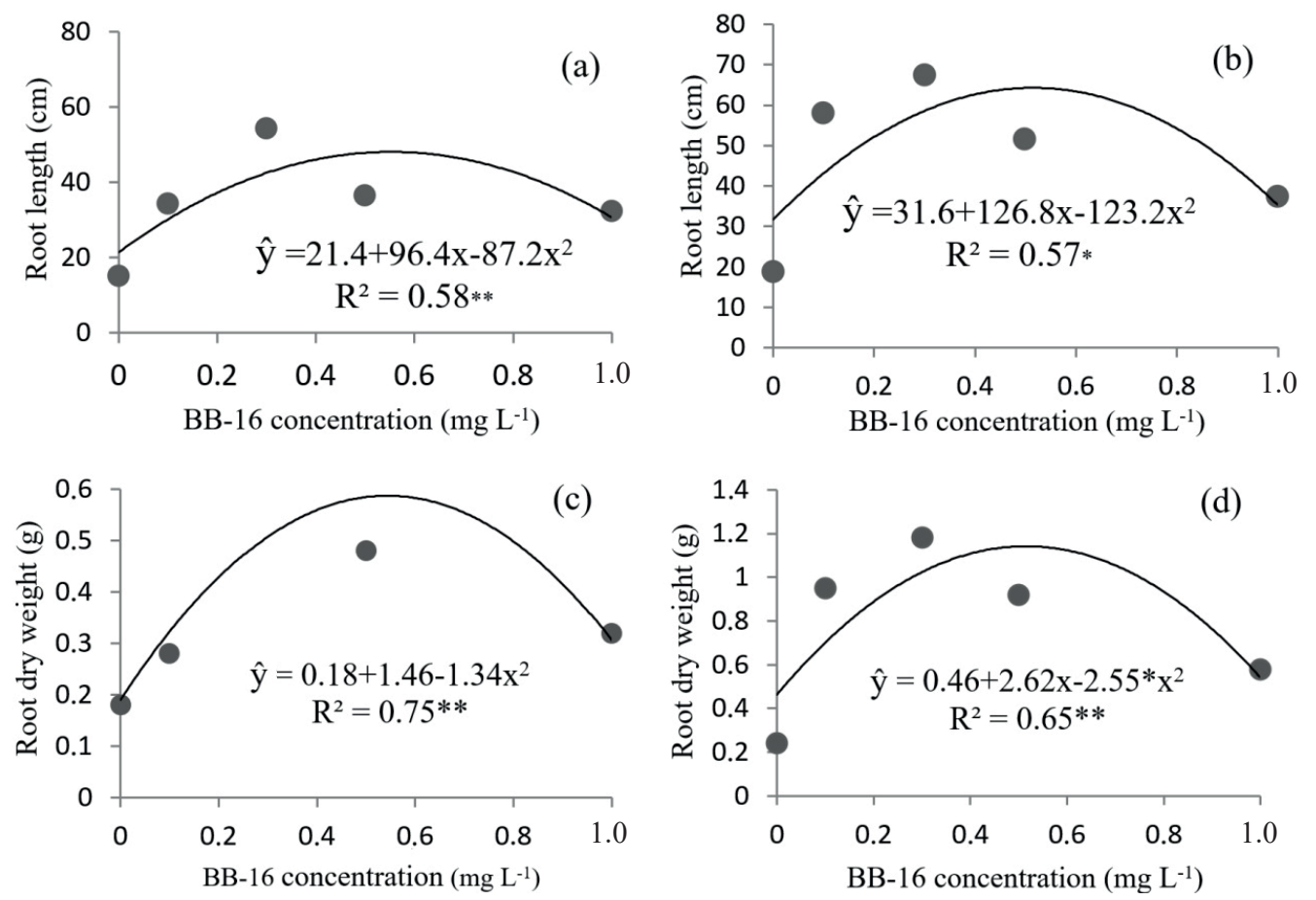

Figure 3. Root length in the winter (a) and spring/summer (b), and root dry weight in the winter (c) and spring/summer (d), in BRS Guaraçá seedlings [P. guajava (L.) x P. guineense (Sw.)] multiplied via minicuttings and treated with increasing concentrations of BB-16 over a 60-day acclimatization period. ** and * significant at 1 and $5 \%$ of probability, respectively.

Table 1. Polynomial equation of leaf dry weight, stem dry weight, root volume, root area and root diameter assessed in the winter and spring/summer, after 60 days of seedling acclimatization.

\begin{tabular}{lcc}
\hline \multicolumn{1}{c}{ Assessed characteristic } & Polynomial equation & $\mathrm{R}^{2}$ \\
\hline & Winter & $0.73^{* *}$ \\
Leaf dry weight & $0.19+3.3 \mathrm{x}-3.14 \mathrm{x}^{2}$ & $0.45^{* *}$ \\
Stem dry weight & $0.081+0.31 \mathrm{x}-0.31 \mathrm{x}^{2}$ & $0.42^{* *}$ \\
Root volume & $0.46+1.41 \mathrm{x}-1.24 \mathrm{x}^{2}$ & $0.60^{*}$ \\
Root area & $34.11+132.16 \mathrm{x}-115.02 \mathrm{x}^{2}$ & - \\
Root diameter & $\mathrm{ns}$ & $0.39^{* *}$ \\
\hline & Spring/summer & $0.33^{* *}$ \\
Leaf dry weight & $0.37+2.34 \mathrm{x}-2.32 \mathrm{x}^{2}$ & $0.43^{* *}$ \\
Root volume & $0.061+0.25 \mathrm{x}-0.28 \mathrm{x}^{2}$ & $0.41^{*}$ \\
Root area & $0.67+1.95 \mathrm{x}-2.0 \mathrm{x}^{2}$ & - \\
Root diameter & $52.46+136.38 \mathrm{x}-141.09 \mathrm{x}^{2}$ & $\mathrm{~ns}$ \\
\hline$* * *$ and & $\mathrm{n}$ &
\end{tabular}

**, * and ns: significant at 1 and $5 \%$ of probability and non-significant, respectively.

\section{CONCLUSIONS}

1. The foliar application of Biobras-16 during the acclimatization of BRS Guaraçá seedlings multiplied via minicuttings produces significant positive effects on shoot and root growth;

2. Concentrations between 0.3 and $0.6 \mathrm{mg} \mathrm{L}^{-1}$ enable the production of better quality seedlings in less time.

\section{ACKNOWLEDGMENTS}

The authors would like to thank the Coordenação de Aperfeiçoamento de Pessoal de Nível Superior (Capes), Fundação de Amparo à Pesquisa do Estado do Rio de Janeiro (FAPERJ) and Conselho Nacional de Desenvolvimento Científico e Tecnológico (CNPq), for the research grants provided during this study. 


\section{REFERENCES}

ALTENDORF, S. Minor tropical fruits: mainstreaming a niche market. Rome: FAO, 2018.

ALTOÉ, J. A.; MARINHO, C. S. Miniestaquia seriada na propagação da goiabeira 'Paluma'. Revista Brasileira de Fruticultura, v. 34, n. 2, p. 576-580, 2012.

ALTOÉ, J. A.; MARINHO, C. S.; FREITAS, I. L. J. Goiabeiras Paluma, Pedro Sato e Cortibel 6 propagadas por miniestaquia e miniestaquia seriada. Ciência Rural, v. 43, n. 8, p. 1351-1356, 2013.

BAGHEL, M.; NAGARAJA, A.; SRIVASTAV, M.; MEENA, N. K.; KUMAR, M. S.; KUMAR, A.; SHARMA, R. R. Pleiotropic influences of brassinosteroids on fruit crops: a review. Plant Growth Regulation, v. 87, n. 2, p. 375-388, 2019.

BOLLE-JONES, E. W. Nutrition of Hevea brasiliensis: I. Experimental methods. Journal of Rubber Research, v. 14, n. 1, p. 183-191, 1954.

CATUNDA, P. H. A.; MARINHO, C. S.; GOMES, M. M. A.; CARVALHO, A. J. C. Brassinosteroide e substratos na aclimatação do abacaxizeiro 'Imperial'. Acta Scientiarum Agronomy, v. 30, n. 3, p. 345-352, 2008.

COSTA, S. R.; SAnTOS, C. A. F.; CASTRO, J. M. C. Assessing Psidium guajava $\times$ P. guineense hybrids tolerance to Meloidogyne enterolobii. Acta Horticulturae, v. 959, n. 1, p. 59-66, 2012.

FREITAS, J. A. A.; MARINHO, C. S.; FREITAS, I. L. J.; SANTOS, P. C.; SILVA, M. P. S.; CARVALHO, A. J. C. Brassinosteroide e fungo micorrízico arbuscular na produção do porta-enxerto tangerineira 'Cleópatra'. Agrária, v. 10, n. 1, p. 54-59, 2015.

FREITAS, S. J.; SANTOS, P. C.; BERILLI, S. D. S.; LOPES, L. C.; CARVAlho, A. J. Brotação, desenvolvimento e composição nutricional de mudas de abacaxizeiro provenientes de gemas axilares submetidas ao brassinosteroide. Agrária, v. 9, n. 1, p. 19-24, 2014.

FREITAS, S. J.; SANTOS, P. C.; CARVALHO, A. J. C.; BERILLI, S. S.; GOMES, M. M. A. Brassinosteroide e adubação nitrogenada no crescimento e estado nutricional de mudas de abacaxizeiro provenientes do seccionamento de caule. Revista Brasileira de Fruticultura, v. 34, n. 2, p. 612-618, 2012.

GOMES, M. M.A.; PINHEIRO, D. T.; BRESSAN-SMITH, R.; CAMPOSTRINI, E. Exogenous brassinosteroid application delays senescence and promotes hyponasty in Carica papaya L. leaves. Theoretical and Experimental Plant Physiology, v. 30, n. 3, p. 193-201, 2018.

GOMES, V. M.; RIBEIRO, R. M.; VIANA, A. P.; SOUZA, R. M. de; SANTOS, E. A.; RODRIGUES, D. L.;
ALMEIDA, O. F. Inheritance of resistance to Meloidogyne enterolobii and individual selection in segregating populations of Psidium spp. European Journal of Plant Pathology, v. 148, n. 3, p. 699-708, 2017.

GOMES, V. M.; SOUZA, R. M.; CORRÊA, F. M. DOLINSK, C. Management of Meloidogyne mayaguensis in commercial guava orchards with chemical fertilization and organic amendments. Nematologia Brasileira, v. 34, n. 1, p. 23-30, 2010.

HOFFMANN, A. Aclimatação de mudas produzidas in vitro e in vivo. Informe Agropecuário, v. 23, n. 1, p. 2124, 2002.

INSTITUTO BRASILEIRO DE GEOGRAFIA E ESTATÍSTICA (IBGE). Levantamento sistemático da produção agrícola. 2020. Disponível em: www.sidra.ibge. gov. Acesso em: 30 mar. 2020.

MARINHO, C. S.; MILHEM, L. M. A.; ALTOÉ, J. A.; BARROSO, D. G.; POMMER, C. V. Propagação da goiabeira por miniestaquia. Revista Brasileira de Fruticultura, v. 31, n. 2, p. 607-611, 2009.

MORILLON, R.; CATTEROU, M.; SANGWAN, B. S.; LASSALLES, J. P. Brassinolide may control aquaporin activities in Arabidopsis thaliana. Planta, v. 212, n. 2, p. 199-204, 2001.

OH, E.; ZHU, J. Y.; BAI, M. Y.; ARENHART, R. A.; SUN, Y.; WANG, Z. Y. Cell elongation is regulated through a central circuit of interacting transcription factors in the Arabidopsis hypocotyl. eLife, v. 3, e03031, 2014.

ONO, O. E.; NAKAMURA, T.; MACHADO, S. R.; RODRIGUES, J. D. Application of brassinosteroid to Tabebuia alba plants. Revista Brasileira de Fisiologia Vegetal, v. 12, n. 3, p. 187-194, 2000.

PEREIRA, F. O. M.; SOUZA, R. M.; SOUZA, P. M.; DOLINSKI, C.; SANTOS, G. K. Estimativa do impacto econômico e social direto de Meloidogyne mayaguensis na cultura da goiaba no Brasil. Nematologia Brasileira, v. 33, n. 2, p. 176-181, 2009.

SANTOS, P. C. dos; SILVA, M. P. da; FREITAS, S. D. J.; BERILLI, S. D. S.; ALTOÉ, J. A.; SILVA, A. D. A.; CARVALHO, A. J. Ácidos húmicos e brassinosteroide no crescimento e estado nutricional de rebentos de coroas de abacaxi. Revista Brasileira de Ciências Agrárias, v. 9, n. 4, p. 532-537, 2014.

TAIZ, L.; ZEIGER, E. Fisiologia vegetal. 4. ed. Porto Alegre: Artmed, 2009.

TANVEER, M.; SHAHZAD, B.; SHARMA, A.; KHAN, E. A. 24-epibrassinolide application in plants: an implication for improving drought stress tolerance in plants. Plant Physiology Biochemistry, v. 135, n. 1, p. 295-303, 2019. 
WEI, Z.; LI, J. Brassinosteroids regulate root growth, development, and symbiosis. Molecular Plant, v. 49, n. 1, p. 86-100, 2016.

YAMAMOTO, L. Y.; BORGES, R. S.; SORACE, M.; RACHID, B. F.; RUAS, J. M. F.; SATO, O.; ASSIS, A. M.; ROBERTO, S. R. Enraizamento de estacas de Psidium guajava (L.) 'Século XXI' tratadas com ácido indolbutírico veiculado em talco e álcool. Ciência Rural, v. 40, n. 5, p. 1037-1042, 2010.

ZHENG, Y.; XU, B.; REN, K.; ZHANG, Y.; WU, J. Impact of soil drench and foliar spray of 24-epibrassinolide on the growth, and quality of field-grown Moringa oleifera in southwest China. Journal of Plant Growth Regulation, v. 36, n. 4, p. 931-941, 2017. 